\title{
Promoting Ecotourism Destination at Jungutan Village, Karangasem, Bali
}

\author{
Ida Ayu Astarini ${ }^{*} \quad$ Adytia Nur Heriyatmo $^{2} \quad$ Ni Komang Yunik Mahardikayanti ${ }^{2}$ \\ Made Erna Susanti ${ }^{2}$ Ida Ayu Made Dwi Utari ${ }^{2} \quad$ Ni Wayan Rai Sukmadewi ${ }^{2}$ \\ Ni Made Winda Savitri Dewi ${ }^{2}$ Ni Wayan Nonik Endrayanti ${ }^{2}$ Wahyu Puji Lestari ${ }^{2}$ \\ Ni Kadek Ariani Dewi ${ }^{2}$ Sagung Istri Santhi Permata Sari ${ }^{2}$ Cindy Larini ${ }^{2}$ \\ Ni Komang Ayu Ariska Dwi Cahyani ${ }^{2}$ Anak Agung Ayu Widiya Ari Santi ${ }^{2}$ Komang Ayu Diantari ${ }^{2}$ \\ 1.Biologi Study Program, FMIPA, Udayana University, Bali \\ 2.Research and Community Service Institution, Udayana University, Bali
}

\begin{abstract}
Bali is well-known around the world as a popular tourist destination due to its nature beauty and cultural uniqueness. Nowadays, tourism in Bali is move toward sustainable tourism or ecotourism, particularly in the undeveloped areas, such as east part of Bali. The aim of this research is to explore and promote the potencia of new tourist destinations in Jungutan Village, Karangasem Regency, Bali. Method used was survey, exploration, direct observation, and interview with community leader and local people. This research was conducted from June - September 2017. Results shows that there are ten tourism destinations at Jungutan Village that are potential to be promoted, i.e. Bukit Nampo or known also as Bukit Surga, Bukit Cemara, Telaga Tista, Salacca plantation at Yeh Kori Village, Citrus plantation at Untalan Village, sweet potato and cassava field at Batu Ampin Village, and trekking to Mount Agung. Most of the community does not aware of the ecotourism potential in Jungutan Village. Therefore, it is very important to enhance their awareness and education on ecotourism, also to develop infrastructure for easy access to new tourist destination.
\end{abstract}

Keywords: agro-tourism, local tourism, sustainable tourism

DOI: $10.7176 / \mathrm{JTHS} / 41-02$

Publication date:May $31^{\text {st }} 2019$

\section{Introduction}

Ecotourism is a type of tourism that allows local people to generate economic benefits from tourism development, while still considering the sustainability of the region (Mensah and Ernest, 2013). Developing rural ecotourism would give a positive impact to rural communities (Asiedu, 2002). Although Bali has long been known as a popular tourist destination, east part of Bali region is still undeveloped on tourism industry, for example Jungutan Village.

Jungutan Village at Bebandem District, Karangasem Regency, located at the east part of Bali, on the foot of Mount Agung. It has a total area of 1.936 ha, consists of 919 ha agricultural land or plantation area, 70 ha rice paddy, 25 ha housing and the rest were offices, backyard, graveyard, and other common infrastructure. Jungutan Village boundaries are in the north: Mount Agung, south: Buhu River of Sibetan and Macang Village, east: Bebandem Village, Buda Keling Village, Bhuana Giri Village, and west: Duda Village. There are 12 sub villages or Dusun at Jungutan Village, i.e. Dusun Jungutan, Dusun Mumbul, Dusun Yeh Bunga, Dusun Pangleg, Dusun Yeh Kori, Dusun Galih, Dusun Untalan, Dusun Abiantihing Kelod, Dusun Abiantihing Kaja, Dusun Tanah Ampo, Dusun Batu Ampin and Dusun Kubu Pangi. Jungutan Village located at $400 \mathrm{~m}-1.200 \mathrm{~m}$ above sea level, with yearly average rainfall $2.907 \mathrm{~mm}$, and average temperature of $25^{\circ} \mathrm{C}$. Kecamatan Bebandem as the central district office located $3 \mathrm{~km}$ away from Jungutan Village; Karangasem Regency government's office located $14 \mathrm{~km}$, and Denpasar as the main province office is $89 \mathrm{~km}$ away from Jungutan Village. There are 7.962 people live in Jungutan Village, 3.975 female and dan 3.987 male, none are foreigner. All of the community is Hindu religion (Profil Desa Jungutan, 2017).

Jungutan Village has a number of education facilities which include one kindergarten, six elementary schools, i.e. SDN 1 Jungutan at Dusun Jungutan, SDN 2 Jungutan at Dusun Kubu Pangi, SDN 3 Jungutan at Dusun Pangleg, SDN 4 Jungutan at Dusun Abiantihing Kaja, SDN 5 Jungutan at Dusun Mumbul, and SDN 6 Jungutan at Dusun Untalan. There is also one middle school: SMP 1 Sibetan, and one high school: SMA 1 Sibetan. The majority of Jungutan villagers $(70 \%)$ are subsistent farmers and the $30 \%$ others are government officer, nurse, and builders.

Jungutan Village sits on the slope of Mount Agung, and therefore has a beautiful surrounding area with Mount Agung and hills as the background. With its natural beauty, Jungutan Village has a high potency to be developed as a new tourism destination. The aim of this study was to find out tourism potencyial of Jungutan Village, which can be developed into a new tourism destination that is sustainable and environmentally friendly. 


\section{Research Method}

This study was conducted from June - September 2017. Survey and direct observation was done throughout all 12 sub-villages (dusun) in Jungutan Village. Interview was conducted with community leaders, which include Jungutan's Perbekel (Head of Jungutan Village), Deputy to Head of Jungutan Village, Head of 12 sub-villages, traditional community leaders, local community and visitors on potential tourism sites which include nature, cultural activities and temples. Samples for local community and visitors were chosen using purposive sampling method. Survey and interview was also conducted on community group meeting known as Sangkep Banjar, to find out which areas to be consider potential tourist destination according to villager perception. Mapping of potential location and potential trekking path was done using Autocad application and finishing was done using Corel Draw program.

\section{Results and Discussion}

Jungutan Village has a high potency to be developed as new tourism destination. Its beautiful natural scenery, agricultural activities, and village cultural activities are the main object for tourism destination. There are three types of tourism potency found in Jungutan Village, i.e. spiritual and cultural based tourism, nature based tourism and agro-tourism.

\subsection{Spiritual and cultural based tourism}

Jungutan Village has three main temples, i.e. Pura Pasar Agung Sibetan, Telaga Tista dan Pura Bangkak. Pura Pasar Agung Sibetan located at Dusun Yeh Kori, at $1.000 \mathrm{~m}$ above sea level. This temple was built using local lava stone with Balinese stone carving, and has beautiful scenery with Mount Agung as the background. Pura Pasar Agung Sibetan (Figure 1) has a cool weather, between $10^{\circ} \mathrm{C}$ in the morning to $20^{\circ} \mathrm{C}$ during midday. It is easily accessible with asphalt road. Parking areas available for small cars, and there is a parking lot available for big cars and busses $500 \mathrm{~m}$ away before reaching the Temple. Pura Pasar Agung Sibetan also popular among visitors who prefer trekking activity to Mount Agung. Visitors usually camp around the areas a day before trekking, or pray at this temple before continue trekking.

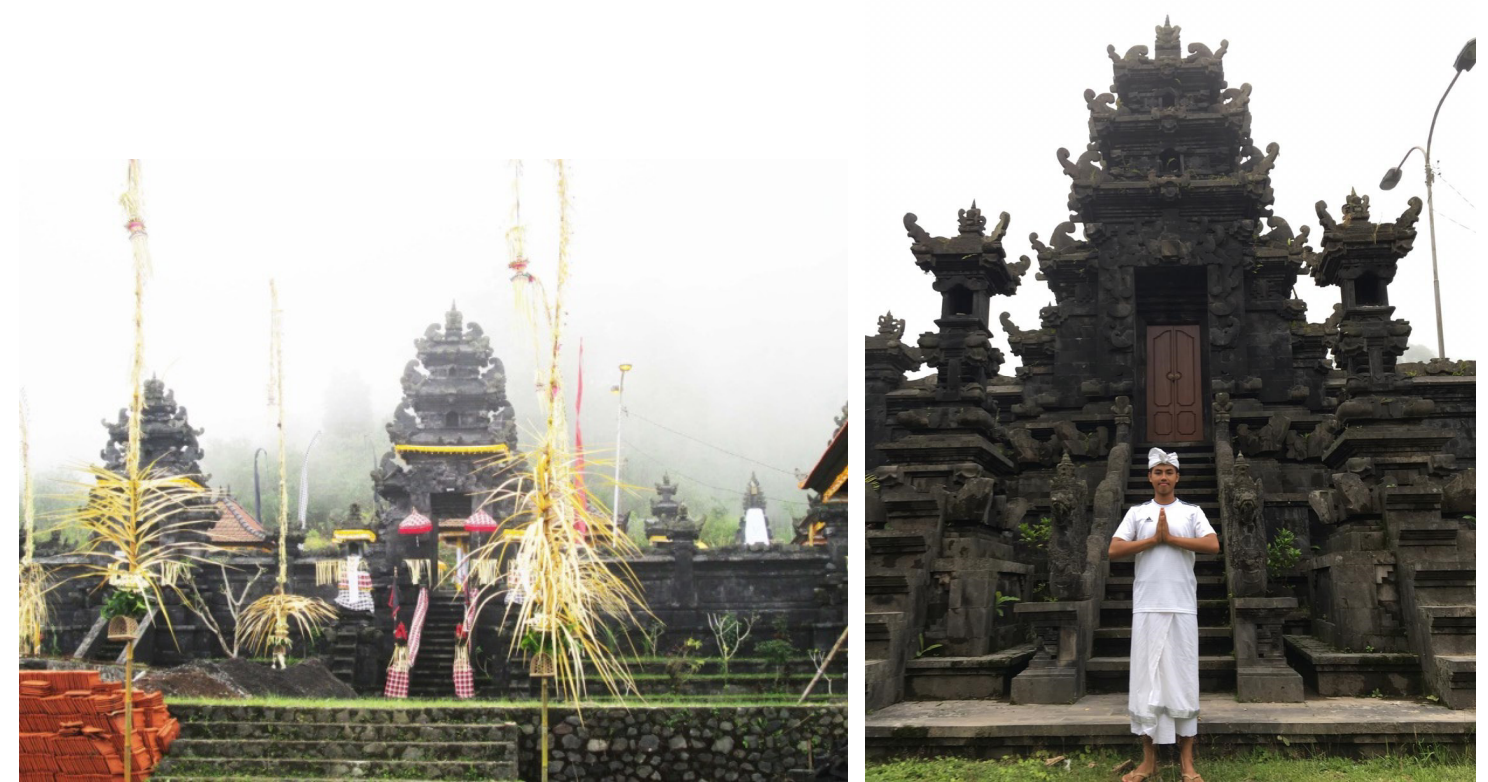

Figure 1. Pura Pasar Agung Sibetan (source: http://jungutan.blogspot.co.id/p/pasar-agung-temple.html) and personal document.

Telaga Tista (Figure 2) is a manmade beautiful pond where the water comes from natural spring water. The pond and the temple was built by the last King of Karangasem Kingdom, in a peaceful areas surrounded by hills and rice paddy. This beautiful pond equipped with bathing places, available for women and men. There is a small temple in the middle of the pond. Temple celebration is held every six months in Balinese calendar (or seven months in Christian calendar) managed by local community. Display of elaborate ornament on the Temple, offerings and traditional activities will attract tourists. Telaga Tista is recommended for trekking activity, purification ritual and meditation. 


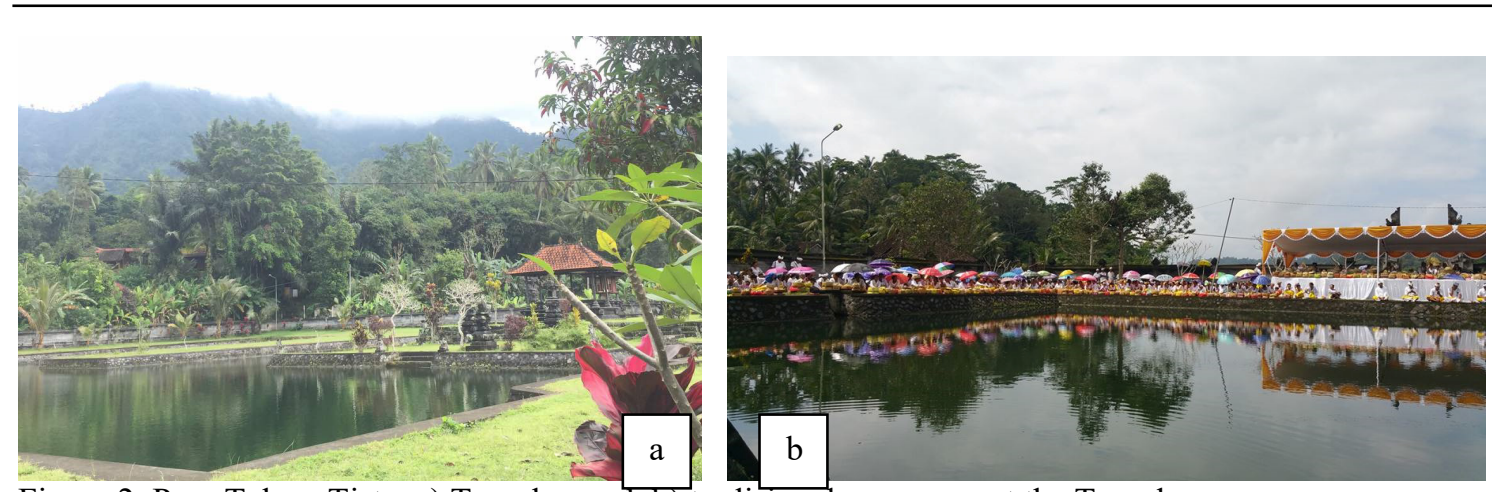

Figure 2. Pura Telaga Tista. a) Temple pond, b) tradisional ceremony at the Temple

Pura Bangkak (Figure 3) is located at Dusun Jungutan. It is symbolized Pura Batu Madeg located at the north of Besakih Temple, the biggest temple in Bali. Ngusaba or celebration at Pura Bangkak was conducted every 20 years, based on legend, where Karangasem King was meditated at Pura Bangkak to be able to have a child and promise to give a big celebration for the Temple if he got a child. After having a child, The King was forgotten about his spell, causing bad luck and he has to give a big celebration every 20 years which include Buffalo in the offering.

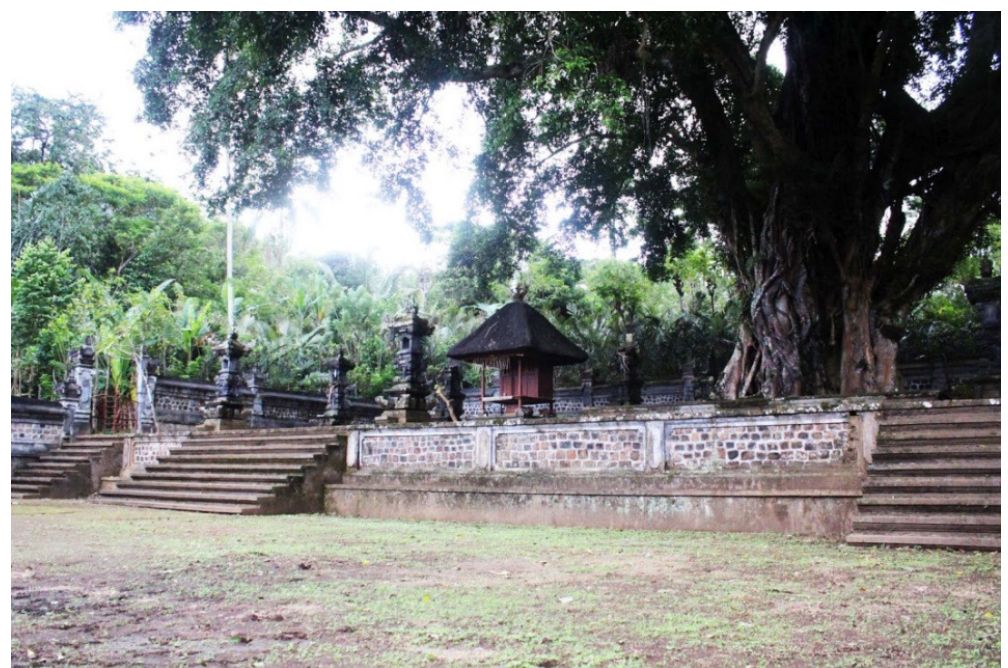

Figure 3. Pura Bangkak (Source: jungutan.blogspot.com/p/pura-bangkak.html)

There are eight temples in the areas which include two Padmasana (Palace for Ratu Ayu Ulundanu and Hyang Surya), Gedung Gaduh (Palace for Hyang Putra Jaya), Dewa Pengelurah, Apit Lawang on the left and right, Pelinggih Manik Bingin and Penyawang Desa. The three temples are visited regularly by local people for every day ritual and offering. Bigger celebration held every six months on Balinese calendar, or seven months on Christian calendar. During temple celebration, elaborate ornament and accessories will be place at the temple, with elaborate ceremony and traditional music and activities going on for three days. The temple celebrations could attract visitors both from Indonesia and abroad. It is recommended that Head of Jungutan Village develop a cultural activities calendar that provide in detail date of temples celebration at Jungutan Village website to attract broader audience.

\subsection{Nature based tourism}

Nature based tourism at Jungutan Village that is highly potencial to be developed is Bukit Nampo, known also as Bukit Surga or Heaven Hill (Figure 4). Bukit Surga is a lookout point at $1.200 \mathrm{~m}$ above sea level, located at Banjar Tanah Nampo. This place has been launched in 2016 by Head of The Karangasem Regency as a new nature based tourism in Karangasem. From the top of the hill, visitors can enjoy spectacular and beautiful green scenery, view of Bali Sea and Mount Agung as the background. Early morning is a perfect time to enjoy sunrise, at midday and afternoon to enjoy fog in the surrounding areas, while in the evening, lights of Karangasem city give special scenery. Bukit Surga is accessible using small car only, due to narrow and windy road. Currently, Government of Karangasem develops a wider road to Bukit Surga for easier access.

Bukit Cemara is another spectacular lookout point located at Dusun Yeh Kori, $1.200 \mathrm{~m}$ above sea level. This location increases its popularity since end of 2016 via social media. Difficult access to reach Bukit Cemara causing fewer visitors compared to nearby Bukit Surga. At the top of the hill, visitors can enjoy peaceful and beautiful scenery of Mount Agung and the surrounding plantation and agricultural land (Figure 4b). There are 
pine trees along the road to Bukit Cemara, which give the name of the hill.

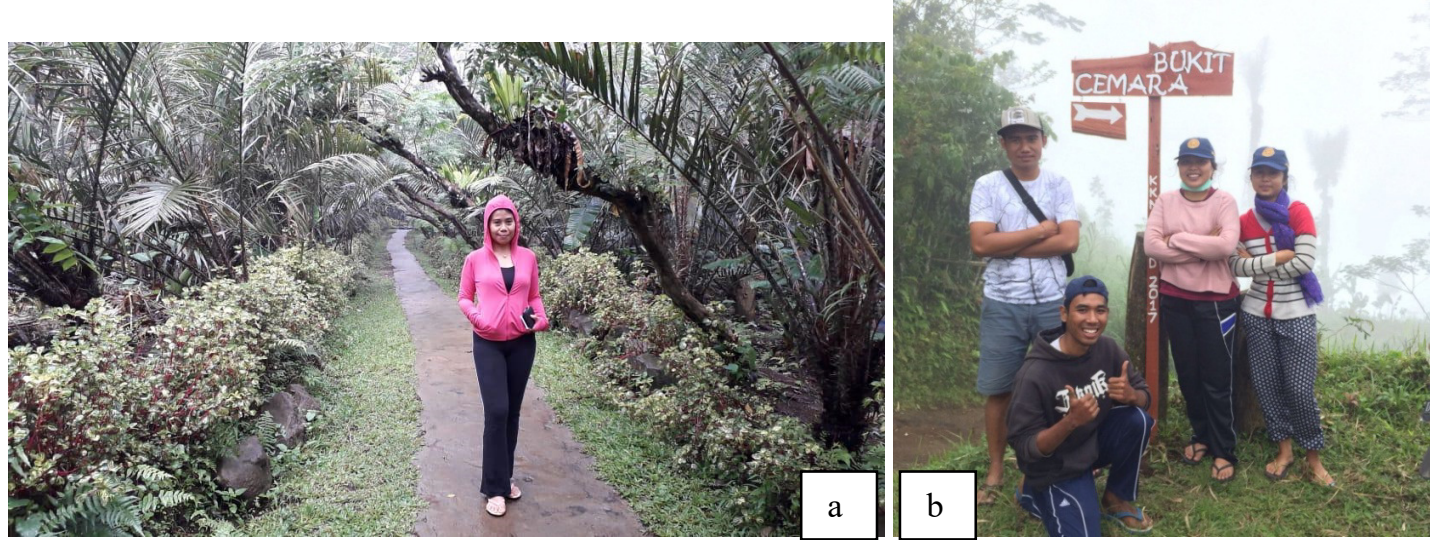

Figure 4. a) Entrance to Bukit Surga with salak plantation on each side, b) Entrance to Bukit Cemara

Trekking is a popular activity for visitors that prefer nature based tourism. From the results of the survey throughout Jungutan Village, we provide a trekking path from Bukit Surga to Bukit Cemara vice versa (Figure 5). This trekking path would allow visitors to enjoy nature, wild life, and agricultural activities along the track.
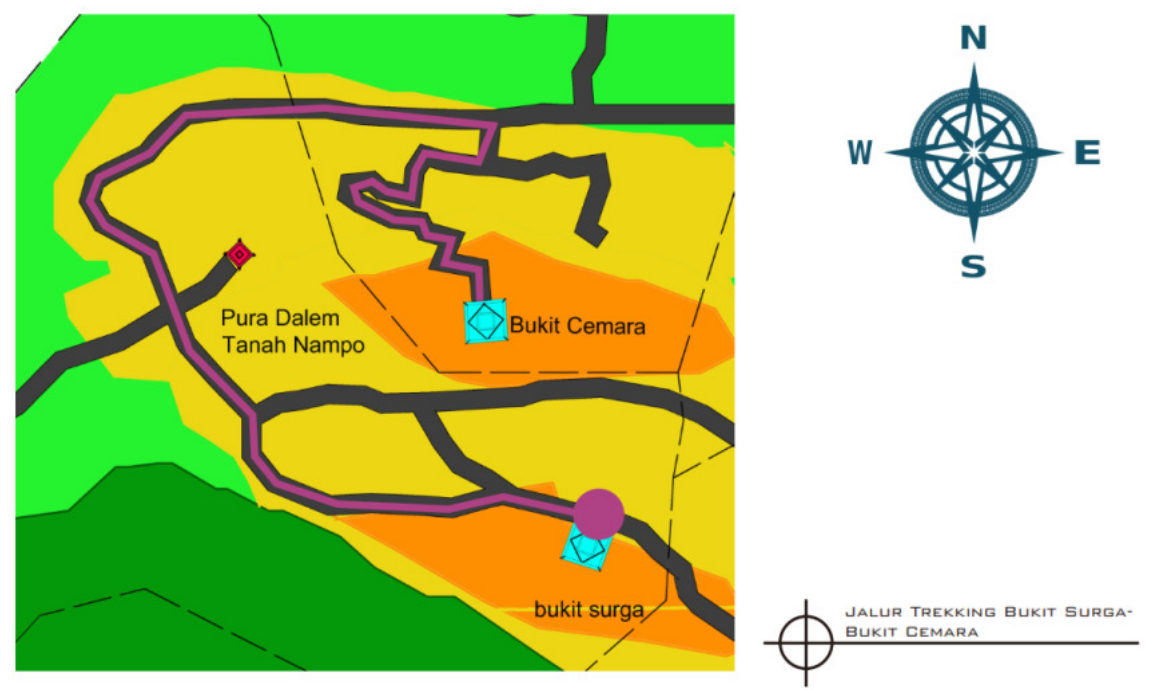

Figure 5. Trekking pathway from Bukit Surga to Bukit Cemara, vice versa

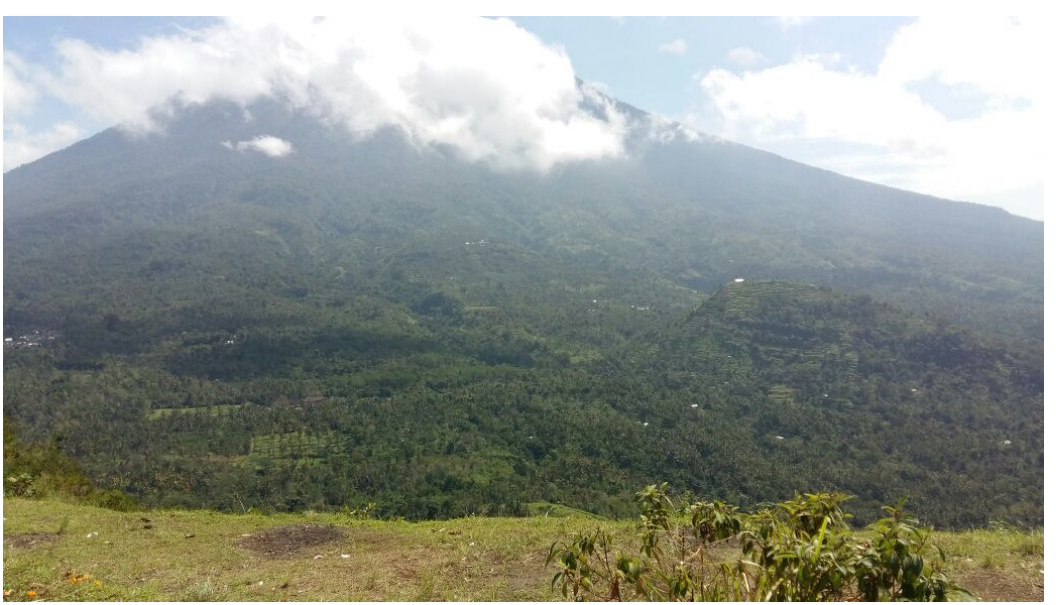

Figure 6. View from Bukit Cemara 
Trekking to Mount Agung is a popular ecotourism activity at Jungutan Village. The community has established tour guiding for tourist, mostly from overseas, to go to Mount Agung via Jungutan. It takes $5-6$ hours to reach the peak of Mount Agung, at elevation $3.031 \mathrm{~m}$ above sea level, with average cost of Rp. 1.000 .000 per guide. Spectacular sunrise view and $360^{\circ} \mathrm{C}$ view of Bali from the peak is the main attraction for visitors.

During observation we found that there is no sign post along the road to guide visitors which way to go to Bukit Surga, Bukit Cemara or trekking to Mount Agung. Therefore, to support ecotourism activities at Jungutan Village, Udayana University together with Ganesha University has put up a number of sign post to help promoting tourist destination and easier access to the touristic areas. Sign post was made using local woods and recyled woods.

\subsection{Agro-tourism}

Besides nature based tourism, Jungutan Village also offers agrotourism potency. As Jungutan located at the slope of Mount Agung with fertile volcanic soils, it gives advantage that varieties of local fruits grow well in this region. In particular, local people grows salak bali (Sallaca edulis), known as snake fruit (Figure 7), which is endemic in Karangasem Regency. In 2014, salak production in Bali was 69.271 ton, from 8.3 million trees, majority produced from Karangasem (Deperindag Provinsi Bali, 2015). Salak plants grow best on $600-700 \mathrm{~m}$ above sea level, and favor volcanic soil.
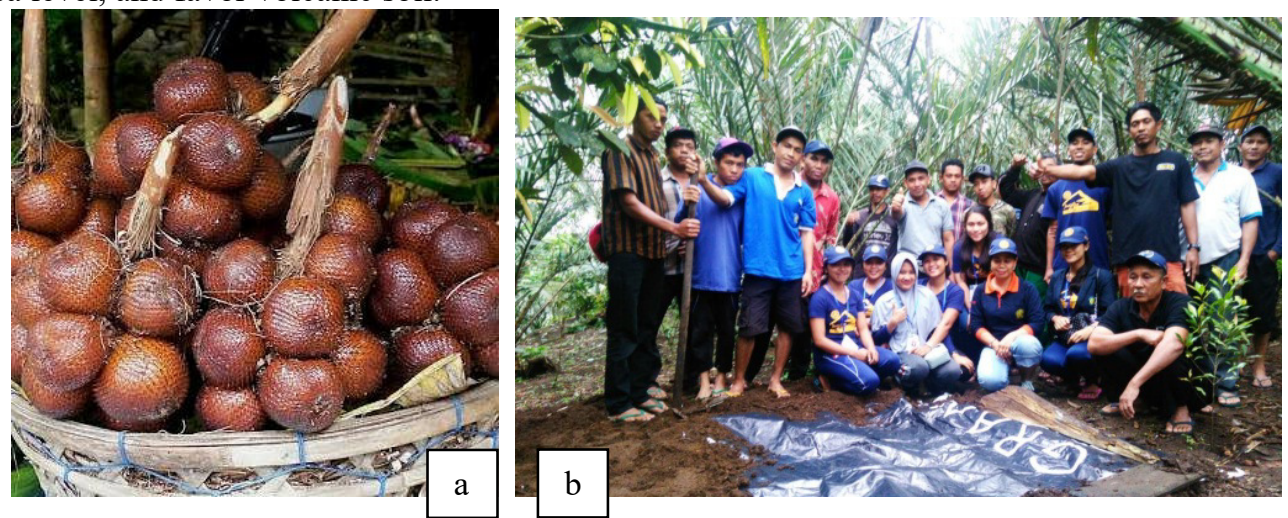

Figure 7. a) Salak Fruit, b) Salak Gula Pasir plantation

The central salak production area in Bali is Karangasem Regency, include Sibetan and Jungutan Village. The plantation belongs to local people. Salak Bali has a unique taste with the combination of sweet and sour taste, crunchy with dark brown rind color (Suter, 1988). There are 12 cultivar salak bali found in the areas, namely Salak Biasa, Salak Gondok, Salak Nenas, Salak Nangka, Salak Penyalin, Salak Boni, Salak Gula Pasir, Salak Toris, Salak Injin, Salak Daun Kelapa, Salak Beringin and Salak Kelapa. Those cultivars were named based on its shape, aroma, taste and rind type that affected by open pollination, soil and climate of the plantation areas (Oka, 1997; Rukmana, 1999). Salak Gula Pasir particularly popular and have a higher value, due to its sweet taste.

With so many varieties and taste of salak bali, it is highly potential to be promoted as one of agrotourism destination. Agrotourism activities propose for the areas include walking around the plantation, learn salak bali farming system, pick your own salak fruit, and taste some product such as wine salak, dodol salak (salak's sweet) and asinan salak (salak fruit salad).

Dusun Untalan at Jungutan Village, produces mandarin citrus (Figure 8). Citrus production in 2013 was 78 ton (BPS Kab. Karangasem, 2014). Dusun Untalan located at $700 \mathrm{~m}-800 \mathrm{~m}$ above sea level with average temperature $19^{\circ} \mathrm{C}-25^{\circ} \mathrm{C}$, make it favorable to grow citrus. Wani (native mango), durian, avocado, banana, cassava, yellow sweet potato and purple sweet potato are some other fruits and horticultural crops produced at Jungutan Village. Salak, wani, durian, avocado, favor volcanic soil and cool weather with average temperature $20^{\circ} \mathrm{C}-25^{\circ} \mathrm{C}$ at $600-700 \mathrm{~m}$ above sea level. The others grow at below $600 \mathrm{~m}$ above sea level with warmer temperature of around $25^{\circ} \mathrm{C}-30^{\circ} \mathrm{C}$. 

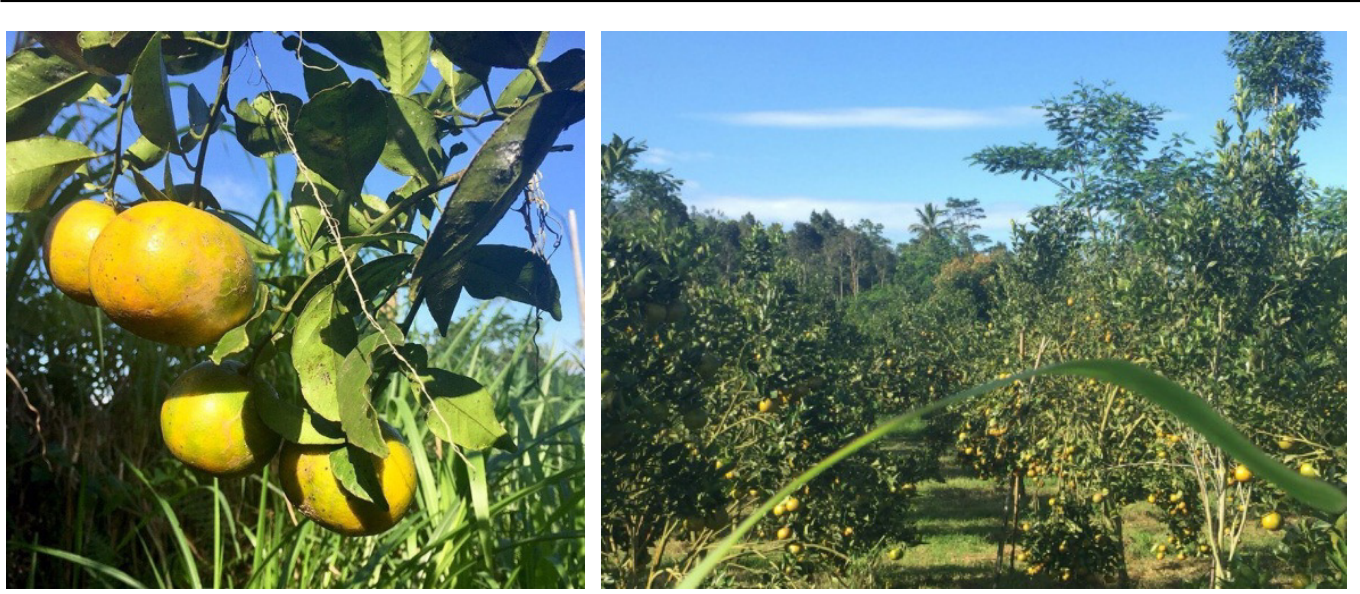

Figure 8. Citrus plantation at Dusun Untalan

To promote all potential tourist destinations in Jungutan Village, Head of Jungutan Village has establish a tourism awareness group, locally known as Kelompok Sadar Wisata (Pokdarwis) consisting youngster community who are interested in tourism activities at Jungutan Village. Currently, this group has run guiding tour for tracking to Mount Agung via Jungutan. Promoting ecotourism would give benefit to the community, generate income for the local people and increase awareness of locals on the important of maintaining their environment to attract visitors from around the world (Fahrian et al., 2015; Islam et al., 2011).

To support development of tourism in Jungutan Village, Udayana University and Ganesha University in Bali, has involved with local community in a number of activities, including socialization on the importance to promote potential tourism destination around Jungutan Village, establishing tracking map and touristic site, introducing the importance of processing fresh produced into process food such as salak fruit salad, purple sweet potato flour, and sweet potato doughnut, introducing the important of good packaging to obtain added value to the selling product.

\section{Conclusion}

In conclusion, Jungutan Village is highly potential for ecotourism. The main attraction to be promoted is spiritual and cultural tourism (Pura Pasar Agung Sibetan, Pura Telaga Tista and Pura Bangkak), nature based tourism (panoramic view from Bukit Surga and Bukit Cemara, trekking to Mount Agung), and agro-tourism (Salak bali, citrus and other tropical fruits and horticulture crops). Efforts to promote this potential tourism destination would include promotion via government website, establishing tourist information center and improvement on supporting facilities and infrastructure.

\section{Acknowledgments}

We would like to thank Bapak Wayan Wastika, Perbekel Jungutan and staffs, for facilitation during study, and LPPM Unud 2017 for opportunity in community service Program.

\section{References}

Asiedu, A. B. (2002), "Making ecotourism more supportive of rural development in Ghana. West African Journal of Applied Ecology", 3, 1-16.

Profil Desa Jungutan. (2017), “Jungutan, Kabupaten Karangasem”, Bali.

BPS Kabupaten Karangasem. (2014). Badan Pusat Statistik.

Dinas Perindustrian dan Perdagangan Provinsi Bali. (2015), Roadmap Pengembangan Industri Agro Unggulan Salak Provinsi Bali.

Fahrian, H.H, Putro, S.P. \& Muhammad, F. (2015), "Potensi Ekowisata di Kawasan Mangrove, Desa Mororejo, Kabupaten Kendal Ecotourism Potential of Mangrove Area at Mororejo Village, Kendal Regency", Biosaintifika, 7(2), 104-111.

Islam, S, Howlader, A, \& Monirul, I. (2011), "Community Based Ecotourism in The Sundarbans of Bangladesh", Rajagiri Journal of Social Development, 3(3), 31-50.

Mensah, I. \& Ernest, A. (2013), "Community Participation in Ecotourism: The Case of Bobiri Forest Reserve and Butterfly Sanctuary in Ashanti Region of Ghana", American Journal of Tourism Management, 2(1A), $34-42$

Oka, I. B. (1997), "Pemuliaan Beberapa Kultivar Salak Bali", Laporan Penelitian. Fakultas Pertanian, Universitas Udayana.

Rahmat, M. A., Umar, S., Wardah \& Sangadji, M. N. (2016), "Potential and Strategy of Ecotourism Management in the Lore Lindu National Park (Case study in Sigi Regency, Central Sulawesi Province, 
Indonesia)", Journal of Tourism, Hospitality and Sports, 22, 110 - 121

Rukmana, R. (1999), Salak: Prospek Agribisnis dan Teknis Usaha Tani. Kanisius. Yogyakarta.

Suter, I. K. (1988), Telaah Sifat Buah Salak Sebagai Dasar Pembinaan Mutu Hasil. Disertasi Fakultas Pascasarjana IPB, Bogor. 